\title{
Pengaruh Reputasi Auditor dan Rasio Dana Pemerintah terhadap Audit Delay dengan Ukuran Perguruan Tinggi Sebagai Variabel Moderasi
}

(Studi Empiris Pada Perguruan Tinggi Negeri Badan Hukum 2016-2018)

\author{
Dyah Novia Nugraheni ${ }^{1)}$ Anggie Kencana Putri ${ }^{2)}$ \\ *Universitas Trisakti \\ 1) 2) Magister Akuntansi Fakultas Ekonomi dan Bisnis \\ E-mail: dyahnovianugraheni@gmail.com ${ }^{1}$ \\ E-mail: anggiekencana147@ @mail.com ${ }^{2}$ )
}

\begin{abstract}
ABSTRAK
Penelitian ini bertujuan untuk mengetahui pengaruh reputasi auditor dan rasio dana pemerintah terhadap audit delay pada PTNBH dengan ukuran perguruan tinggi sebagai pemoderasi. Populasi penelitian adalah seluruh PTNBH periode 2016-2018. Penelitian ini menggunakan metode kuantitatif. Populasi yang digunakan penelitian ini adalah PTN di lingkungan Kementerian Pendidikan dan Kebudayaan sebanyak 122 PTNBH. Data yang dipakai merupakan Laporan Keuangan independen Akuntan Publik. Alat analisis data dan uji hipotesis dilakukan menggunakan program SPSS 25, hipotesis diuji menggunakan analisis Moderated Regression Analysis (MRA). Hasil pengujian hipotesis menunjukkan Reputasi Auditor berpengaruh positif terhadap Audit Delay, begitu juga Rasio Dana Pemerintah berpengaruh positif terhadap Audit Delay. Untuk pemoderasi menunjukkan bahwa ukuran perguruan tinggi memperlemah pengaruh positif reputasi auditor terhadap audit delay. Akan tetapi, ukuran perguruan tinggi memperkuat pengaruh positif dana pemerintah terhadap audit delay.
\end{abstract}

Kata kunci: audit delay, reputasi auditor, rasio dana pemerintah, ukuran perguruan tinggi.

\section{ABSTRACT}

This study aims to determine the effect of the auditor's reputation and the ratio of government funds to audit delay in the Legal Entity State University $(P T N B H)$ with the size of universities as moderating. The population of this research is all PTNBH for the period of 2016-2018. The type of research is field research using quantitative methods. The population in this study was PTN within the Ministry of Education and Culture, namely 122 PT with the sample of this research was 11 PTNBH. The data used is secondary data obtained from the official website of PTNBH for an independent Public Accountant report. Methods of data analysis and hypothesis testing were performed using the SPSS 25 program, all hypotheses were tested using Moderated Regression Analysis (MRA). The results showed that the Auditor's Reputation had a positive effect on Audit Delay, as did the Government Fund Ratio positively affecting Audit Delay. The moderating variable shows that the size of the college is not able to moderate the effect of the auditor's reputation on audit delay. However, the size of the college is able to moderate (strengthen) the effect of government funds on audit delay.

Keywords: audit delay, auditor reputation, government fund ratio, college size. 


\section{Pendahuluan}

Salah satu terobosan yang dilakukan Menteri Pendidikan dan Kebudayaan tahun 2020 ini adalah terbitnya Peraturan Menteri Pendidikan dan Kebudayaan nomor 4 Tahun 2020 tentang perubahan Permendikbud nomor 88 Tahun 2014 tentang Perubahan PTN menjadi PTNBH, karena dengan peraturan tersebut perguruan tinggi negeri akan mendapatkan lebih banyak kemudahan dan flesibilitas untuk berubah statusnya amenjadi perguruan tinggi negeri badan hukum serta perolehan derajat kemampuan Perguruan Tinggi Negeri dalam rangka 1) melaksanakan Tridharma Perguruan Tinggi yang berkualitas 2). Dengan beerdasarkan prinsip tata kelola yang baik untuk melakukan pengelolaan pada struktur PTN 3). mampu memenuhi standar kelayakan finansial dalam tingkatan minimum, 4) melakukan peranan dan fungsi sosial dengan penuh tanggung jawab, dan 5). Ikut andil dalam pembangunan perekonomian secara aktif.

TABEL 1.1

JuMLAH PERGURUAN TINGGi NEGERI DI INDONESIA

\begin{tabular}{|c|l|c|c|c|c|}
\hline \multirow{2}{*}{ No } & \multirow{2}{*}{$\begin{array}{c}\text { Perguruan } \\
\text { Tiggi }\end{array}$} & \multicolumn{4}{|c|}{ JUMLAH PTN } \\
\cline { 3 - 6 } & Sakker & BLU & PTBH & Jumlah \\
\hline 1 & Universitas & 32 & 23 & 8 & 63 \\
\hline 2 & Institut & 9 & & 3 & 12 \\
\hline 3 & $\begin{array}{l}\text { Sekolah } \\
\text { Tinggi }\end{array}$ & - & - & - & - \\
\hline 4 & Akademik & - & - & - & - \\
\hline 5 & $\begin{array}{l}\text { Akademik } \\
\text { Komunitas }\end{array}$ & 4 & - & - & 4 \\
\hline 6 & Politeknik & 41 & 2 & & 43 \\
\hline & Jumlah & 86 & 25 & 11 & 122 \\
\hline
\end{tabular}

Sumber : PDDIKTI, 2019

Berdasarkan tabel 1.1 tersebut jumlah perguruan tinggi negeri berbadan hukum saat ini baru 11 PTN atau 9,02\% dari jumlah PTN di Indonesia, sehingga dengan kebijakan Menteri Pendidikan dan Kebudayaan tersebut diharapkan terjadi perubahan yang siginifikan untuk Perguruan Tinggi Negeri Berbadan Hukum.Saat ini terdapat 11 Perguruan Tinggi Negeri yang sudah berubah menjadi Perguruan Tinggi Negeri Berbadan Hukum yaitu :

TABEL 1.2

Perguruan Tinggi Negeri Berbadan Hukum DI INDONESIA

\begin{tabular}{|c|l|c|}
\hline No & \multicolumn{1}{|c|}{ Perguruan Tinggi } & Dasar Hukum Pendirian \\
\hline 1. & Universitas Indonesia & PPnomor 152 tahun 2000 \\
\hline 2. & $\begin{array}{l}\text { Universitas Gajah } \\
\text { Mada }\end{array}$ & PP nomor 153 tahun 2000 \\
\hline 3. & $\begin{array}{l}\text { Institut Pertanian } \\
\text { Bogor }\end{array}$ & PP nomor 154 tahun 2000 \\
\hline 4. & $\begin{array}{l}\text { Institut Teknologi } \\
\text { Bandung }\end{array}$ & PP nomor 56 tahun 2003 \\
\hline 5. & $\begin{array}{l}\text { Universitas Sumatera } \\
\text { Utara }\end{array}$ & $\begin{array}{l}\text { Universitas Pendidikan } \\
\text { Indonesia }\end{array}$ \\
\hline 6. & Universitas Airlangga & PP nomor 30 tahun 2006 \\
\hline 8. & Universitas Padjajaran & PP nomor 80 tahun 2014 \\
\hline 9. & $\begin{array}{l}\text { Universitas } \\
\text { Diponegoro }\end{array}$ & PP nomor 81 tahun 2014 \\
\hline 10. & Universitas Hasanudin & PP nomor 82 tahun 2014 \\
\hline
\end{tabular}

\begin{tabular}{|c|l|c|}
\hline 11. & $\begin{array}{l}\text { Institut } \quad \text { Teknologi } \\
\text { Sepuluh Nopember }\end{array}$ & PP nomor 83 tahun 2014 \\
Sumber : Dirjen Dikti (2019)
\end{tabular}

Saat ini jumlah perguruan tinggi negeri berbadan hukum berjumlah 11 PTN dari 122 PTN di Indonesia atau 9,02\%, sehingga dengan kebijakan Menteri Pendidikan dan Kebudayaan tersebut diharapkan terjadi perubahan pada Perguruan Tinggi Negeri Berbadan Hukum secara signifikan.

Perguruan Tinggi Negeri Badan Hukum mempunyai peraturan yang lebih mudah disesuaikan terkait aspek akademik dan non akademik, misalnya tetap mempertahankan akuntabilitas pada pengelolaan keuangannya. Pertanggungjawaban finansial adalah perwujudan tanggung jawab terhadap implementasi anggaran dalam bentuk laporan posisi keuangan (neraca), laporan aktivitas, laporan arus kas, dan Catatan atas Laporan Keuangan (CaLK), sebagaimana ditentukan menurut Standar Akuntansi Keuangan (SAK), yang disetujui oleh pimpinan Perguruan Tinggi (Rektor) dengan pembubuhan tanda tangan kemudian dilaporkan kepada Majelis Wali Amanat (MWA) dalam waktu paling lama lima bulan dari penutupan tahun buku.

Kewajiban untuk mempertanggungjawabkan manajemen finansial negara pada PTNBH dilakukan melalui pelaksanaan audit yang dilakukan oleh Badan Pemeriksa Keuangan atau Kantor Akuntan Publik, karena PTN Badan Hukum memperoleh dan menggunakan dana yang berasal dari APBN dan non APBN. Penyampaian laporan audit tidak dapat dipisahkan dari kewajiban pemerintah sebagaimana diamanatkan Undang-Undang Nomor 17 tahun 2003 pasal 30 ayat (1) bahwa DPR menerima laporan dari Presiden untuk mempertanggungjawabkan pelaksanaan APBN yang sudah diperiksa Badan Pemeriksa Keuangan, pada bulan Juni atau maksimal dalam waktu 6 (enam) bulan. Jarak antara berakhirnya periode akuntansi hingga laporan hasil audit dilaporkan merupakan selang waktu yang ditimbulkan pada proses pemeriksaan akuntansi, hal ini juga dikatakan sebagai audit delay. Berikut ini jumlah hari dan rata-rata audit delay pada PTN Badan Hukum tahun 2016-2018 yaitu :

TABEL 1.3

AUDIT DELAY PTN BADAN HUKUM TAHUN 2016-2018

\begin{tabular}{|c|l|r|r|r|l|}
\hline \multirow{2}{*}{$\begin{array}{c}\text { N } \\
\text { o }\end{array}$} & \multicolumn{2}{|c|}{ Perguruan Tinggi } & \multicolumn{4}{|c|}{ Jumlah hari audit delay } \\
\cline { 3 - 7 } & & $\begin{array}{c}201 \\
6\end{array}$ & $\begin{array}{c}201 \\
7\end{array}$ & $\begin{array}{c}201 \\
8\end{array}$ & $\begin{array}{l}\text { Rata } \\
\text { Rata }\end{array}$ \\
\hline 1 & Universitas Indonesia & 88 & 120 & 100 & 102 \\
\hline 2 & Universitas Gajah Mada & 100 & 103 & 100 & 101 \\
\hline 3. & Institut Pertanian Bogor & 222 & 68 & 88 & 126 \\
\hline 4 & Institut Pertanian Bandung & 89 & 88 & 126 & 101 \\
\hline 5 & Universitas Sumatera Utara & 132 & 74 & 148 & 118 \\
\hline 6 & $\begin{array}{l}\text { Universitas Pendidikan } \\
\text { Indonesia }\end{array}$ & 152 & 115 & 117 & 128 \\
\hline
\end{tabular}




\begin{tabular}{|c|c|c|c|c|c|}
\hline 7 & Universitas Airlangga & 95 & 118 & 112 & 108 \\
\hline 8 & Universitas Padjajaran & 151 & 95 & 88 & 111 \\
\hline 9 & Universitas Diponegoro & 100 & 100 & 64 & 88 \\
\hline 10 & Universitas Hasanudin & 128 & 75 & 98 & 100 \\
\hline 11 & $\begin{array}{l}\text { Institut Teknologi Sepuluh } \\
\text { Nopember }\end{array}$ & 100 & 115 & 113 & 109 \\
\hline & Rata-rata & 123 & 97 & 105 & 108 \\
\hline
\end{tabular}

Sumber: Data olahan

Berdasarkan tabel 1.3 rata-rata audit delay untuk PTN Badan Hukum selama Tahun 2016-2018 menunjukan rata-rata 108 hari, pada tahun 2016 selama 123 hari, tahun 2017 selama 97 hari dan tahun 2018 selama 105. Audit delay terpendek terjadi pada tahun 2018 yang terjadi pada Universitas Diponegoro sedangkan terlama pada tahun 2016 pada Institut Pertanian Bogor selama 222 hari. Tentu ini fenomena menarik untuk diteliti faktor-faktor yang mempengaruhi audit delay, karena audit berpengaruh terhadap keputusan investor untuk melakukan pembelian saham, sebagai perbandingan dengan perusahaan-perusahaan yang go publik, menunjukan bahwa audit delay pada perusahaan pertambangan 2013-2017 selama 70 hari [1], audit delay pada perusahaan manufaktur 2013-2015 selama 79 hari, audit delay pada PEMDA di Indonesia selama 137 hari [2], audit delay pada seluruh perusahaan yang listing di Bursa Efek Indonesia selama 79 hari dan audit delay pada pemerintah daerah di Jawa selama 87 hari. Memperhatikan hal tersebut maka waktu 108 hari yang dibutuhkan sehingga terjadi audit delay pada PTN Badan Hukum masih terbilang tinggi di banding perusahaan-perusahaan yang sudah go publik

Penelitian-penelitian terdahulu menunjukan bahwa audit delay dipengaruhi berbagai faktor, salah satunya ukuran perusahaan dimana bahwa kecil atau besarnya ukuran suatu perusahaan dan termasuk juga tingkan profitabilitas yang dimilikinya juga mempengaruhi jangka waktu proses terjadinya audit delay, hal ini diperkuat dengan penelitian Dharatika [3] yang menjelaskan bahwa Audit Delay dapat dipengaruhi oleh besarnya ukuran perusahaan karena ukuran perusahaan yang lebih besar maka data perusahaan yang dimiliki akan lebih kompleks yang dengan demikian membutuhkan jangka waktu lebih panjang daripada perusahaan berukuran kecil dalam membuat laporan audit sehingga dapat memperpanjang audit report delay, begitu juga dengan ukuran perusahaan dengan reputasi KAP sebagai variabel moderating yang mempunyai pengaruh dengan Audit Delay karena perusahaan besar lebih memiliki data yang kompleks dan dengan menggunakan auditor dari KAP yang bereputasi baik maka hasilnya akan semakin efisien.

Sedangkan penelitian lain Dewi [4], menunjukan hasil yaitu audit delay tidak dipengaruhi oleh ukuran daerah yang diproksikan dengan banyaknya entitas akuntansi pada pemerintah daerah sedikit atau banyak waktu dalam melakukan audit tidak terpengaruh oleh jumlah entitas yang dimiliki.
Opini audit terbukti dapat mempengaruhi audit delay karena makin baik sebuah opini yang didapatkan pemerintah daerah menandakan bahwa tata kelola yang dijalankan oleh pemerintah daerah sudah baik.

Penelitian [5] menunjukan bahwa ukuran perusahaan menunjukkan pengaruh terhadap audit delay secara negatif, sementara audit delay pada kantor akuntan publik tidak dipengaruhi oleh profitabilitas reputasi hal ini diperkuat dengan penelitian Virginia bahwa audit delay tidak terpengaruh oleh opini audit secara signifikan Berdasarkan penelitian terdahulu bahwa peneliti berikutnya bias mengembangkan lingkup objek penelitian, pada lebih dari satu bidang atau perusahaan yang masuk dalam daftar Bursa Efek Indonesia bias juga ada bidang-bidang lainnya, hal ini diperkuat peneliti Sahida [6], agar penelitian diperluas cakupannya baik perusahaan keuangan dan non keuangan.

\section{Kajian Pustaka}

\section{Teori Keagenan}

Untuk menjelaskan tentang audit delay, kita uraikan dahulu landasan teori yang mendukung ruang lingkup audit delay yaitu teori keagenan. Menurut [7], teori teori keagenan (agency theory) menjelaskan bahwa hubungan prinsipal dengan agen, dimana agen mendapatkan kewenangan dari prinsipal untuk membuat keputusan dan menimbulkan biaya sehingga dengan tanggungjawab ini maka laporan keuangan auditan yang lambat akan dapat diatasi. Prinsipal adalah pihak yang mengelola investasi dari para investor. Prinsipal sebagai agen harus memberikan laporan dalam periode waktu yang telah ditentukan agar investor tetap percaya dan mau menanamkan investasinya kembali. Agen yang dapat dipercaya akan mudah mendapatkan modal dari para penanam saham dan para pihak yang ingin memasukkan dananya. Menurut teori agensi bahwa prinsipal atau pihak pengelola mempunyai informasi yang lebih besar daripada investor maka dari itu prinsipal lebih diuntungkan. Dalam hal ini ada pula yang disebut sebagai asimetri informasi.

Elemen yang krusial yang harus dipertimbangkan untuk mengimplementasikan teori agensi yaitu audit delay. Pada penelitian ini audit delay digunakan sebagai variabel terikat. Ketepatan waktu dalam penyajian laporan keuangan berkaitan dengan audit delay, informasi yang tepat waktu lebih berharga dibanding informasi yang terlambat bahkan berpengaruh kepada jumlah informasi yang dilaporkan kepada principal dan dapat mengakibatkan informasi yang diperoleh menjadi asimetris dan juga sebagai elemen dalam teori agensi. Agen harus menyampaikan laporan sesuai waktu yang ditentukan, apabila lewat dari waktu yang ditetapkan akan berpengaruh kepada asimetris infomasi yang diperoleh oleh pihak prinsipal dari pihak manajemen 
atau agensi atau shareholder, dan dimana prinsipal seharusnya mendapatkan laporan keuangan yang transparan.

Audit delay memiliki hubungan yang sangat relevan pada ketaatan agen terhadap laporan keuangan yang harus disampaikan kepada pemangku kepentingan. Karena jika diberikan pada waktu yang tepat akan memberi dampak positif terhadap penilaian agen, sedangkan laporan keuangan yang tidak patuh akan menimbulkan asimetris informasi dan menurunkan citra perusahaan atau agen.

\section{Teori Sinyal}

Signalling theory merupakan informasi terkait perusahaan yang mengindikasikan suatu hal atau sinyalmen untuk penanam modal, dalam membuat investasi didalam perusahaan tersebut. Sinyal bisa dalam bentuk informasi keuangan maupun non keuangan bahwa perusahaan yang dimaksud mempunyai kinerja yang lebih prospektif berbanding perusahaan lainnya. Menurut teori ini informasi positip yang disampaikan manajemen perusahaan akan mendorong sentimen positip terhadap harga saham.

Sinyal yang diberikan pihak pengelola dapat menjadi indikasi kepada investor apakah perusahaan yang akan dituju sebagai tempat menanamkan modal memang layak dan reliabilitas. Sinyal juga memberikan informasi mengenai kesehatan dari sebuah perusahaan. Sinyal berasal dari laporan keuangan disampaikan dalam waktu yang telah ditentukan.

Signalling Theory (teori sinyal) menjelaskan bahwa informasi yang disampaikan manajemen perusahaan akan mempengaruhi pengambilan keputusan perusahaan terhadap pihak eksternal, baik investor, rekanan, pelaku usaha dan pemerintah, meskipun informasi ini menyangkut peristiwa yang sudah terjadi, namun akan digunakan sebagai bahan pertimbangan untuk menentukan keputusan diwaktu berikutnya. Hal ini merupakan petunjuk atau sinyal untuk para penanam modal terkait menentukan keputusan berinvestasi pada sebuah perusahaan.

Dengan adanya sinyal yang positif maka investor akan berani membuat keputusan menanamkan sahamnya. Sinyal positif juga dijadikan alat ukur kesehatan perusahaan dan kemudian bisa menjadi penilai keberhasilan manajemen atau prinsipal dalam mengelola dana yang dipercayakan.

Beberapa dampak terjadi pada respon pasar karena informasi yang baik ataupun informasi yang buruk yang diperoleh terkait sebuah perusahaan. Dengan kondisi ini maka keterlambatan dalam penyampaian informasi yang diakibatkan dari audit delay akan direspon negatif oleh pasar sehingga audit delay berpangaruh terhadap pengambilan keputusan. Pasar yang memberikan respon positif tentunya akan mempengaruhi pandangan penanam modal, jika respon positif maka berarti perusahaan telah mampu menunjukkan kinerja dan reputasi yang baik untuk para pihak yang berkepentingan pada perusahaan.

Pelaporan keuangan merupakan sebah bentuk pertanggungjawaban dari proses pengelolaan keuangan entitas berupa pengelolaan sumberdaya, kewajiban, penghasilan perusahaan dan lainnya untuk dikomunikasikan pada semua pihak terkait secara langsung ataupun tidak langsung [12]. Tujuan pelaporan keuangan dalam entitas sektor publik adalah bentuk pertanggungjawaban (IPSASB, 2010). Dengan demikian, informasi yang mempunyai kualitas yang baik harus memiliki perlakuan kualitatif untuk digunakan Stakeholder. Menurut Dewi Karakteristik kualitatif informasi dari laporan keuangan yaitu bisa dimengerti, terkait, dan reliabel atau andal. Ketepatan waktu dalam menyampaikan laporan juga merupakan unsur yang penting dalam pelaksanaan audit.

\section{Pengertian Audit}

Pengertian audit menurut [8], Audit adalah tindakan memeriksa laporan keuangan oleh pihak independen, obyektif dan kompeten atas laporan keuangan beserta bukti pendukung, untuk diberi penilaian tentang kesesuaian dengan standar yang telah ditetapkan, sedangkan menurut Susan Irawadi, Audit merupakan tindakan-tindakan yang dilakukan untuk memperoleh bukti secara sistematis dan melakukan evaluasi atas transaksi ekonomi yang disajikan dalam laporan keuangan agar dapat memberikan pemikiran tentang kewajaran laporan oleh pihak yang independen dengan mengacu kepada standar

Pendapat lainnya [9] mendefinisikan audit adalah the examination of information of evidence accumulation in a company to share to shareholders or relevant parties about the congruency or mistake in the information and determined creterias. Yang dapat diartikan bahwa audit adalah pemeriksaan terhadap informasi dari berbagai bukti yang terkumpul mengenai suatu perusahaan untuk disampaikan kepada penanam modal atau pihak terkait mengenai kesesuaian atau kekeliruan informasi dan kriteria yang telah ditentukan.

Dalam lingkup pengelolaan keuangan negara menjelaskan tahapan pemeriksaan dari proses mencari sumber masalah, pemetaan, analisa dan evaluasi bukti obyektif, serta kompeten sesuai standar keuangan negara untuk menilai menilai kewajaran penyajian laporan keuangan secara benar, cermat, kredibel, dan andal informasi pengelolaan keuangan negara.

Dari berbagai definisi diatas, berikut ini beberapa karakteristik yang dapat disimpulkan dari pengertian audit :

1. Suatu informasi yang diukur berdasarkan kriteria yang ditetapkan

Sebelum melakukan audit, harus memahami dahulu kriteria informasi yang ditetapkan, kemudian kebenarannya diverifikasikan untuk 
digunakan sebagai bukti dalam pelaksanaan pemeriksaan yang valid. Kriteria tersebut misalnya PSAK dan PSAP.

2. Entitas ekonomi

Pemeriksaan dilakukan terhadap suatu entitas dalam periode tertentu, baik instansi pemerintah, swasta, organisasi lainnya untuk periode semesteran maupun tahunan

3. Kegiatan mengumpulkan dan mengevaluasi bahan bukti.

Pada tahap dilakukan pemeriksaaan ada beberapa hak yang disertakan termasuk melakukan pengumpulan dan pengevaluasian bukti-bukti yang dipandang sudah valid dan terkait dengan proses audit yang sedang dilaksanakan. Kegiatan itu dimulai dengan menentukan berbagai bukti yang dibutuhkan hingga tahap pengevaluasian dan penilaian layak atau tidaknya informasi disampaikan untuk mencapai tujuan pengauditan.

4. Independen dan Kompetensi dalam pelaksanaan Pemeriksa yang bertugas diharuskan memiliki ilmu dan pengalaman mengaudit yang sudah mumpuni, auditor harus independent dalam bersikap dalam arti tidak melakukan keberpihakan atau mengarah pada kepentingan salah satu pihak tujuanya agar opini yang diberikan adil dan benar.

5. Pelaporan Audit

Hasil pemeriksaan atau laporan audit merupakan bentuk komunikasi yang disampaikan oleh auditor kepada perusahaan terkait semua objek yang diaudit agar laporan yang dihasilkan bisa digunakan oleh para pihak terkait yang membutuhkan laporan tersebut.

Menurut UU No. 15 Tahun 2004 ruang lingkup pemeriksaan keuangan negara di Indonesia meliputi audit kinerja, dan audit untuk tujuan khusus dan audit laporan keuangan yang meliputi pemeriksaan terhadap kondisi finansial instansi pemerintah sesuai dengan SAP, Audit dalam hal kinerja untuk melihat kinerja baik dari sudut ekonomis, efisiensi dan efektivitas pengelolaan keuangan negara sementara audit dengan tujuan khusus maksudnya audit yang dilakukan dan bukan merupakan audit laporan keuangan maupun audit kinerja [10]

$$
\text { Laporan kinerja PTNBH disusun }
$$
berpedomana kepada SAK. Laporan keuangan PTNBH terdiri atas 1). neraca; 2).laporan aktivitas,3).laporan arus kas dan4) catatan atas laporan keuangan. Sebagai organisasi publik maka PTNBH memiliki kewajiban untuk mempertanggungjawabkan pengelolaan keuangan Negara Untuk mengukur pelaksanaannya maka diperlukan Audit oleh BPK.

\section{Pengertian Audit Delay}

Dalam penyampaian pertanggungjawaban Pengelolaan keuangan negara, dimana PTNBH yang mendapat dana dari APBN wajib mengikuti ketentuan yang diamanatkan peraturan bahwa Laporan Keuangan PTNBH yang sudah diaudit BPK atau KAP wajib disampaikan paling lambat 6 Bulan setelah tahun anggaran berakhir. Periode antara akhir tahu anggaran dengan terbitnya laporan audit oleh BPK atau KAP merupakan audit delay.

Audit delay merupakan perbedaan antara tanggal pelaporan keuangan sampai dengan hari penerbitan laporan pemeriksaan audit..Audit delay yang lama harus dihindari dan diharapkan pelaporan keuangan disajikan dengan benar penting untuk berkerja secara sismatis bahwa proses audit dilakukan secara tepat dan cepat sejak perencanaan, pekerjaan lapangan sampai kepada pelaporan. Untuk itu diperlukan kecermatan, sistematis dan kewaspadaan terhadap audit penyajian laporan keuangan. Audit Delay dapat dipengaruhi oleh ukuran perusahaan karena ukuran perusahaan yang lebih besar maka data perusahaan yang dimiliki akan lebih kompleks yang dengan demikian membutuhkan jangka waktu lebih panjang daripada perusahaan berukuran kecil dalam membuat laporan audit sehingga dapat memperpanjang audit report delay, begitu juga dengan ukuran perusahaan dengan reputasi KAP sebagai variabel moderating yang mempunyai pengaruh terhadap Audit Delay karena Entitas besar yang lebih memiliki data yang kompleks dan dengan menggunakan auditor dari KAP yang bereputasi baik akan menghasilkan laporan yang efesien.

Dengan demikian maksud dari audit delay adalah waktu yang diperlukan oleh seorang auditor untuk membuat hasil pemeriksaan dalam bentuk laporan audit yang menjelaskan tentang prestasi atau pencapain keuangan dari perusahaan tersebut. Waktu penyampaian laporan ini bisa diukur dengan tanggal laporan keuangan tahunan yang lama dengan laporan keuangan yang baru yang dikeluarkan oleh auditor.

\section{Reputasi Auditor}

Reputasi Auditor dibentuk berdasarkan Undang-Undang nomor 5 tahun 2011 tentang Akuntan Publik. Pada saat manajemen sebuah persahaan menentukan Kantor Akuntan Publik mana yang ditugaskan untuk membuat laporan pemeriksaan keuangan, maka ada beberapa hal yang akan dipertimbangkan lebih dulu oleh manajemen yaitu, reputasi, kualitas, keahlian audit yang dimiliki oleh auditor independent. KAP yang mempunyai reputasi baik bisa melaksanakan audit dengan efektif dan efesien, tepat dan cepat, sehingga perusahaan bisa menggunakan laporan audit pada waktu yang dibutuhkan.

Reputasi Auditor adalah ukuran dari kepercayaan pengguna dan pandangan atas nama baik, pencapaian dari kantor tersebut. Sedangkan [9] 
menjelaskan bahwa Reputasi KAP merupakan citra yang dimiliki auditor yang menjalin kerjasama dengan KAP internasional antara lain Big Four Worldwide Accounting Firm (Big 4).

Kualitas hasil audit ditentukan oleh banyak faktor, tetapi diduga bahwa Kantor Publik yang bereputasi atau berafiliasi dengan KAP dunia berpengaruh terdap citra Auditor. KAP yang memiliki reputasi memiliki sikap independensi auditor dalam melaksanakan pemeriksaan. Diduga KAP dengan ukuran besar memiliki reputasi yang baikdan lebih tinggi dibanding KAP yang ukuran kecil. Auditor dengan reputasi yang baik memiliki harapan menghasilkan laporan audit yang optimal. KAP yang mempunyai reputasi yang baik dan terkenal karena tingkat independensinya akan dijaga dalam status yang besar sehingga para pemeriksanya bekerja lebih teliti agar tidak terjadi kesalahan pemeriksaan sehingga reputasinya menjadi buruk. KAP dengan reputasi yang baik, maka memiliki kecenderungan lebih bertanggungjawab

\section{Rasio Dana Pemerintah}

Dana PTNBH merupakan dana yang diberikan untuk Perguruan Tinggi untuk menyelenggarakan dan mengelola pendidikan sedangkan pemerintah mengembangkan sistem penyediaan dana PTNBH melalui subsidi secara khusus ditujukan bagi PTNBH yang didapatkan dari APBN. Adapun mekanisme pendanaan PTNBH bisa diperoleh dari 1). APBN dan 2). selain APBN.

Sumber dana PTNBH bersumber dari APBN disediakan dan disebut sebagai bantuan pendanaan atau berdasarkan aturan dan undang-undang lainnya yang berlaku. Bantuan Pendanaan PTNBH dimasukkan dalam anggaran pada kementerian pendidikan dan kebudayaan, bantuan Pendanaan PTNBH yang dialokasikan dari APBN merupakan bagian dari $20 \%$ dana yang disediakan untuk Pendanaan PTNBH dikelola secara otonom. Dana ini dimanfaatkan untuk membayar gaji dosen, tenaga pendidik, biaya operasionalisasi, investasi dan pengembangan.

Memperhatikan hal tersebut maka Perguruan Tinggi Negeri Badan Hukum (PTNBH), memiliki alokasi anggaran yang diperoleh dari APBN dan alokasi dana yang diusahakan oleh PTN Badan Hukum tersebut. Alokasi anggaran yang diberikan pemerintah dilakukan dalam APBN yang dapat digunakan untuk :

1. Biaya operasional digunakan untuk a). Menyelenggarakan kegiatan belajar mengajar, b. Melakukan riset, c. Melakukan kegiatan praktek ke lapangan masyarakat dan d. Mengelola manajemen perguruan tinggi.

2. Biaya dosen digunakan untuk pengajar non PNS termasuk utnuk membayar gaji dan tunjangan, seperti tunjangan profesi, jabatan, biaya makan/ honor menurut tugasnya dari pimpinan PTN
Badan Hukum berdasarkan undang-undang dan aturan yang ditetapkan.

3. Biaya tenaga kependidikan untuk disediakan untuk membayar gaji dan juga berbagai tunjangan untuk tenaga pendidik yang bukan PNS.

4. Biaya investasi adalah dana yang disiapkan untuk mengadakan fasilitas dan berbagai kebutuhan untuk menyelenggarakan proses pendidikan di PTN termasuk pembangunan gedung, jaringan, membeli perlengkapan teknologi informasi, aset tetap, jalan dan juga jembatan, intangible asset atau aset-aset lain namun tidak termasuk pengadaan lahan.

5. Biaya pengembangan termasuk dana bantuan yang dialokasikan untuk mengembangkan proses pendikan di PT, untuk meningkatkan keahlian dan keilmuan pada pengajaran, pengembangan lain yang dicantumkan strategis PTNBH.

\section{Ukuran Perguruan Tinggi}

Ukuran perguruan tinggi secara teoritis dapat disamakan dengan ukuran perusahaan, Perguruan Tinggi yang besar akan menyajikan lebih banyak informasi daripada perguruan tinggi yang lebih kecil ukurannya. Perusahaan dengan ukuran besar mempunyai gambaran positif dimata masyarakat dan pada umumnya diawasi oleh pihak yang memiliki kepentingan secara ketat. Tekanan lebih cenderung dirasakan oleh perusahaan yang besar sehingga dalam penyampaian hasil pemeriksaan keuangannya dilakukan secara tepat waktu

Ada beberapa aspek untuk mengukur besar kecilnya sebuah perusahaan. Termasuk diantaranya aset keseluruhan yang dimiliki jumlah keseluruhan penjualan, kapitalisasi pasar, jumlah tenaga kerja dan lainnya. Ukuran memberikan gambaran skala yang dilihat dari besaran aktiva. Pemerintah dan investor biassanya akan lebih memperhatikan perusahaan skala besar dibandingkan perusahaan skala kecil [11]. Selain itu [12] ada anggapan bahwa perusahaan yang besar mampu melaksanakan pengauditan dengan lebih cepat dibandingkan perusahaan kecil karena kontrol yang dimiliki lebih kuat. Berkaitan dengan hal itu maka laporan audit harus disediakan oleh perusahaan besar dalam waktu yang lebih cepat. Tetapi terlepas dari itu perusahaan yang memiliki total asset yang dibesar dikategorikan sebagai perusahaan yang besar. Auditor juga membutuhkan waktu yang lebih panjang jika aset keseluruhan perusahaan juga besar.

Audit delay kemungkinan lebih bisa diatasi oleh perusahaan dengan manajemen yang lebih besar dengan insentif yang lebih baik. Munsif et al [12] menemukan variabel ukuran perusahaan berpengaruh signifikan, hasil penelitian tersebut sependapat dengam penelitian Ariyani [13] yaitu yang menunjukkan bahwa audit delay dapat dipengaruhi oleh ukurang perusahaan. Semakin besar perusahaan yang diaudit maka waktu pengauditan menjadi lebih lama dan mungkin menyebabkan pemeriksaan harus 
lebih detail dan kompels sehingga waktu untuk pelaksanaannya juga lebih panjang agar opini yang dihasilkan menjadi kuat karena bukti-bukti yang diperoleh juga mendukung.

Untuk pemerintah daerah, jumlah entitas akuntansi memberi informasi bahwa daerah yang memiliki masalah yang besar membutuhkan entitasentitas untuk menangani masalah yang timbul di daerah tersebut, [14] Menurut [14] hal yang harus dilakukan oleh pemda adalah membuat konsolidasi dari hasil pemeriksaan keuangan dari berbagai bentuk transaksi akuntansi yang ada pada pemda tersebut dan tidak harus mencatatnya satu persatu terhadap semua hal terkait penggunaan dana yang dianggarkan [4]

Perusahaan yang besar memiliki kecenderungan lebih tepat waktu dalam membuat laporan dibanding perusahaan kecil. Karena ada sistem informasi yang lebih baik digunakan oleh perusahaan besar dibanding perusahaan yang lebih kecil ukurannya. Maka dari itu proses audit dapat dilakukan lebih cepat oleh perusahaan besar. Pada penelitian ini ukuran Perguruan Tinggi ditentukan menurut aset total yang dimiliki PTNBH. Asset merupakan indikasi ketersediaan dana untuk menjalankan kegiatan operasional perguruan tinggi. Disamping itu, aset juga merepresentasikan reputasi dan kualitas perguruan tinggi secara keseluruhan.

Pendidikan Tinggi merupakan tingkat pendidikan setelah pendidikan atas yang termasuk strata sarjana, magister, diploma, doktor, spesialis, profesi, yang dilaksanakan oleh perguruan tinggi menurut sistem pendidikan di Indonesia [16] Dalam perkembangannya Perguruan Tinggi Negeri kita mengenal ada PTNBH,PTNBLU, dan PTN Satker

\section{Pengaruh Reputasi Auditor Terhadap Audit Delay}

Untuk meningkatkan kredibilitas pelaporan keuangan, stakeholders membutuhkan pemeriksaan dari auditor independent sebagaimana dijelaskan oleh [17] reputasi kantor akuntan publik merupakan gambaran dari perusahaan yang dibentuk sejak kantor itu didirikan berdasarkan kualitas dari audit yang dihasilkan bagi berbagai perusahaan yang telah menggunakan jasanya dan tidak ada tuntutan hukum ataupun kekeliruan ketika pemeriksaan telah selesai dilakukan dan besaran jumlah bayaran yang dibebankan atas pemeriksaan tersebut sesuai dengan layanan yang diberikannya. Maka dari itu reputasi dari kantor akuntansi publik adalah level atau peringkat yang didapatkan dari penilaian kliennya misalnya perusahaan dalam melaksanakan pemeriksaan audit dan menyelesaikan tugas pengauditan tepat waktu menurut reputasi yang dimilikinya.

KAP dikelompokkan kedalam dua jenis yaitu big four dan nonbig four[18]. Reputasi yang dimiliki oleh KAP big four disebabkan adanya teknologi yang mendukung, fasilitas yang lebiih baik, pelatihan dan para ahli yang lebih kompeten. Maka dari itu pelaksanaan audit biasanya juga menjadi lebih cepat dan tepat dan jarak pelaksanaan audit lebih singat maka dari itu bisa disebut bahwa audit delay bisa dipengaruhi oleh reputasi yang dimiliki oleh kantor akuntasi publik. Namun hasil penelitian berbeda dikemukakan [5] dimana reputasi KAP tidak mempengaruhi audit delay. Tidak ada pengaruh dari reputasi KAP terhadap rentang waktu untuk menyampaikan hasil pemeriksaan dan reputasi KAP tidak mempengaruhi audit delay secara signifikan.

Penulis berpendapat bahwa Reputasi auditor akan mepengaruhi pelaksanaan audit karena penilaian yang akan diberikan oleh KAP yang mempunyai reputasi yang baik akan mendorong organisasi untuk segera menyelesaikan pelaporannya.

\section{Pengaruh Rasio Dana Pemerintah Terhadap Audit Delay}

Penganggaran diperlukan untuk peningkatan kinerja sebuah institusi pemerintah (Umar, 2013) Penganggaran diperlukan untuk peningkatan kinerja sebuah institusi pemerintah [18] Dana PTNBH yang disiapkan oleh pemerintah untuk menyelenggarkan dan mengelola proses pendidikan di PTNBH dari subsidi APBN. Adapun bentuk dan mekanisme pendanaannya 1).APBN dan 2). selain APBN

\section{Kerangka Konseptual}

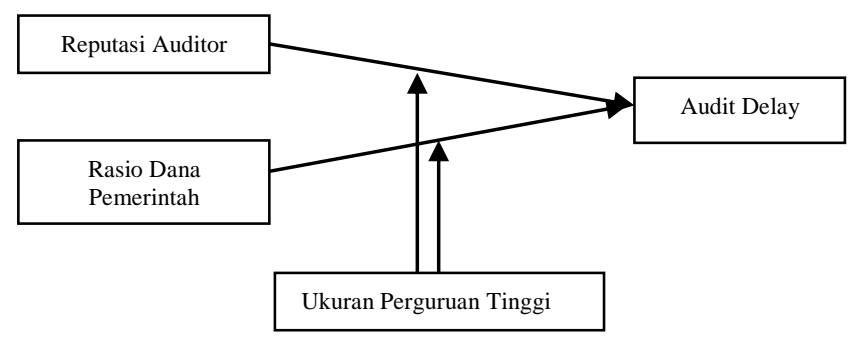

Gambar 1.1 Kerangka Konseptual

\section{Pengembangan Hipotesis}

Hipotesis adalah jawaban sementara untuk rumusan masalah yang dikemukakan dalam penelitian. Maka dari itu rumusan permasalahan akan dibuat dalam bentuk pertanyaaan yang sistematis. Hipotesis disebut sementara karena masih bersifat dugaan dan akan mendapatkan kepastian setelah diperoleh hasil analisis dengan teori, penelitian terkait, dan berbagai literatur yang relevan yang telah dikumpulkan. Adapun hipotesis penelitian ini yang dibuat menurut rumusan permasalahan dan kerangka pemikiran yaitu:

H1 = Reputasi auditor berpengaruh positif terhadap audit delay.

$\mathrm{H} 2$ = Rasio dana pemerintah berpengaruh Positif terhadap audit delay.

H3 = Ukuran perguruan tinggi memoderasi pengaruh reputasi auditor terhadap audit delay

$\mathrm{H} 4=$ Ukuran perguruan tinggi memoderasi pengaruh rasio dana pemerintah terhadap audit delay 


\section{Metode Penelitian \\ Desain Penelitian}

Jenis penelitian yang dilakukan adalah penelitian lapangan dengan pendekatan kuantitatif. Populasi untuk penelitian menggunakan Perguruan Tinggi Negeri di lingkungan Kementerian Pendidikan dan Kebudayaan yaitu 122 Perguruan Tinggi terdiri dari 86 PTN Satuan Kerja, 25 PTN Badan Layanan Umum dan 11 PTN Badan Hukum. Sampel penelitian ini adalah Perguruan Tinggi Negeri Badan Hukum di lingkungan Kementerian Pendidikan dan Kebudayaan sebanyak 11 PTN Badan Hukum. Penelitian ini merupakan jenis penelitian kuantitatif melihat bagaimana pengaruh antara Variabel "X" (Reputasi Auditor dan Rasio Dana Pemerintah) terhadap variabel "Y" (Audit Delay) yang dimoderasi oleh varibel "Z" (Ukuran Perguruan Tinggi).Data yang digunakan adalah data Sekunder. Yang didapatkan dari situs resmi PTN Badan Hukum untuk laporan independen Akuntan Publik terhadap PTN Badan Hukum dari tahun 2016-2018.

\section{Populasi dan Sampel}

Populasi mencakup obyek atau subyek dari wilayah generalisasi yang memiliki karakteristik dan kualias yang spesifik yang telah ditentukan lebih dulu oleh peneliti untuk dikaji dan selanjutnya menarik kesimpulan. [19] Populasi penelitian ini adalah Perguruan Tinggi Negeri di lingkungan KEMENDIKBUD yaitu 122 Perguruan Tinggi terdiri dari 86 PTN Satuan Kerja, 25 PTN Badan Layanan Umum dan 11 PTN Badan Hukum.

Sampel penelitian ini adalah Perguruan Tinggi Negeri Badan Hukum di lingkungan Kementerian Pendidikan dan Kebudayaan sebanyak 11 PTN Badan Hukum yaitu :

1. Universitas Indonesia

2. Universitas Gajah Mada

3. Institut Pertanian Bogor

4. Institut Pertanian Bandung

5. Universitas Sumatera Utara

6. Universitas Pendidikan Indonesia

7. Universitas Airlangga

8. Universitas Padjajaran

9. Universitas Diponegoro

10. Universitas Hasanudin

11. Institut Teknologi Sepuluh Nopember

Kriteria sampel yang terdapat pada penelitian ini sebagai berikut:

1. Laporan Keuangan PTN Badan Hukum periode $2016-2018$

2. Laporan Auditor Independen PTN Badan Hukum periode 2016-2018

3. Alokasi dana dari Pemerintah Indonesia terhadap PTN Badan Hukum periode 2016-2018

4. Daftar KAP yang melakukan audit terhadap laporan keuangan PTN Badan Hukum periode 2016-2019

\section{Definisi dan Pengukuran Variable}

Dalam penelitian ini yang menjadi variable terikat adah audit delay. Ketepatan waktu dalam penyajian laporan keuangan berkaitan dengan audit delay, informasi yang tepat waktu lebih berharga dibanding informasi yang terlambat bahkan berpengaruh kepada jumlah informasi yang dilaporkan kepada principal dan dapat mengakibatkan informasi yang diperoleh menjadi asimetris dan juga sebagai elemen dalam teori agensi.

Adapun definisi operasional dan pengukuran dari variabel penelitian dapat dideskripsikan sebagaimana berikut ini:

\section{Audit Delay}

Audit delay adalah rentang waktu yang diperlukan untuk melaksanakan pengauditan oleh auditor sejak tanggal berakhirnya laporan keuangan hingga laporan terbaru dikeluarkan. Audit delay diukur secara kuantatif dengan satuan hari, yaitu :

Audit Delay $=$ Tanggal laporan keuangan - tanggal laporan audit

\section{Reputasi Auditor}

KAP dibedakan kedalam dua jenis, yaitu KAP Big Four dan KAP domestik Four. Kriteria yang digunakan adalah :

a. Bila PTN Badan Hukum diaudit oleh KAP BigFour maka diberikan nilai 2,

b. Bila PTN Badan Hukum diaudit oleh KAP nonBig Four diberi nilai 1.

\section{Rasio Dana Pemerintah}

Pendanaan PTN Badan Hukum dana yang disiapkan oleh pemerintah untuk menyelenggarakan dan mengelola proses pendidikan di PTNBH dari mengembangkan sistem penyediaan dana untuk perguruan tinggi melalui subsidi APBN. Rasio Dana Pemerintah menunjukan adalah perbandingan dana bantuan pemerintah terhadap total pendanaan PTNBH

Rasio Dana Pemerintah $=$
Alokasi bantuan pemerintah/Total pendanaan PTN

\section{Ukuran Perguruan Tinggi}

Ukuran perguruan tinggi negeri badan hukum (PTNBH) dinilai berpedoman kepada ukuran PTNBH yang diproksikan dengan Ln Total Asset karena setiap perguruan tinggi memiliki total aktiva yang berbeda. Dalam Penelitian ini penulis akan mengasumsikan perusahaan adalah Perguruan Tinggi Negeri Badan Hukum

Ukuran PTNBH = Ln Total Asset (Total Asset)

\section{Hasil Penelitian Dan Pembahasan}

Penelitian terhadap laporan hasil audit KAP terhadap 11 (sebelas) Perguruan Tinggi Negeri Badan Hukum (PTNBH) menyangkut Audit Delay, reputasi auditor, rasio dana pemerintah dan ukuran Perguruan Tinggi 
maka diperoleh informasi sebagai berikut :

\section{Hasil Uji Regresi Ganda}

Pengujian ini dilaksanakan berdasarkan tingkan signifikansi dari masing-masing hubungan. Level of significance $(\alpha)$ yang ditentukan yaitu sebesar $5 \%$ artinya hanya $5 \%$ batas toleransi yang diperbolehkan. Dalam hal ini, level of convidence dari pengujian yaitu 95\%. Jika ditemukan pvalue $<0.05$ maka variabel independen berpengaruh signifikan terhadap variabel dependen.Persamaan regresi untuk hipotesis penelitian ini sebagai berikut:

\begin{tabular}{|c|c|c|c|c|c|c|}
\hline \multicolumn{7}{|c|}{ Coefficients $^{\mathrm{a}}$} \\
\hline \multirow[b]{2}{*}{ Model } & & \multicolumn{2}{|c|}{$\begin{array}{l}\text { Unstandardized } \\
\text { Coefficients }\end{array}$} & \multirow{2}{*}{$\begin{array}{c}\begin{array}{c}\text { Standardized } \\
\text { Coefficients }\end{array} \\
\text { Beta } \\
\end{array}$} & \multirow[b]{2}{*}{$t$} & \multirow[b]{2}{*}{ Sig. } \\
\hline & & B & $\begin{array}{l}\text { Std. } \\
\text { Error }\end{array}$ & & & \\
\hline \multirow[t]{3}{*}{1} & (Constant) & 5.565 & 3.292 & & 1.690 & .094 \\
\hline & Reputasi Auditor & .729 & .067 & .728 & 10.940 & .000 \\
\hline & Rasie Dana Remerintah & .152 & .066 & .154 & 2.318 & .023 \\
\hline
\end{tabular}

Audit Delay $=5.565+729+152$

Berdasarkan hasil uji regresi berganda terlihat variabel independen Reputasi auditor berpengaruh signifikan terhadap audit delay ( $\mathrm{p}$-value $0,000<$ $0,05)$, begitu juga variabel independen rasio dana pemerintah berpengaruh signifikan terhadap audit delay (p-value 0,023 < $0,05)$

\section{Pengujian Hipotesis}

Pengujian Hipotesis Pertama $\left(\mathrm{H}_{1}\right)$

Variabel Reputasi Auditor memiliki nilai koefisien regresi $(\beta)=0,729$ dengan nilai $\operatorname{sig} \mathrm{t}=0.000$ dimana $0.000<0.05$ sehingga H1 adalah Reputasi Auditor berpengaruh positif terhadap Audit Delay. Penulis bahwa reputasi auditor berpengaruh positif terhadap ketepatan waktu dalam pelaporan audit, hingga mempersingkat audit delay

\section{Pengujian Hipotesis Pertama $\left(\mathbf{H}_{2}\right)$}

Variabel Rasio dana pemerintah dengan nilai koefisien regresi $(\beta)=0,152$ dengan nilai sig $\mathrm{t}=0.023$ dimana $0.023<0.05$ sehingga $\mathrm{H} 2$ diterima yaitu Rasio Dana Pemerintah berpengaruh positif terhadap Audit Delay. Pengujian ini menunjukan semakin tinggi rasio dana pemerintah maka akan berpengaruh terhadap waktu audit delay, karena akan semakin banyak dokumen untuk pertanggungjawaban sehingga memerlukan waktu lama untuk auditor melakukan pemeriksaan.

\section{Pengujian Hipotesis Ketiga $\left(\mathrm{H}_{3}\right)$}

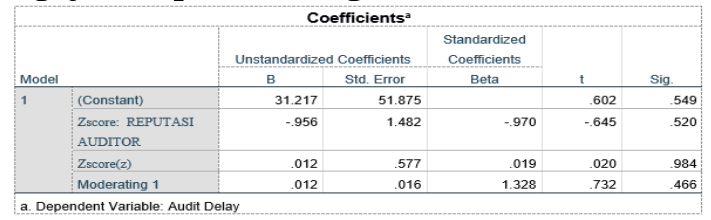

Pada table diatas dapat dilihat bahwa hubungan antara Reputasi Auditor dengan Ukuran Perguruan Tinggi dengan koefisien regresi positif 0,012 sesuai dengan arah yang diprediksikan, serta memiliki nilai signifikansi $0,466<0,05$ sehingga hipotesis 3 ditolak artinya variabel moderasi menunjukkan bahwa ukuran perguruan tinggi memperlemah pengaruh positif reputasi auditor terhadap audit delay. Hasil ini menunjukan bahwa ukuran PTNBH memperlemah pengaruh positif reputasi auditor terhadap audit delay, karena auditor dalam bekerja menerapkan sikap independensi sehingga tidak ada pengaruh ukuran PTNBH terhadap audit delay.

\section{Pengujian Hipotesis Keempat $\left(\mathrm{H}_{4}\right)$}

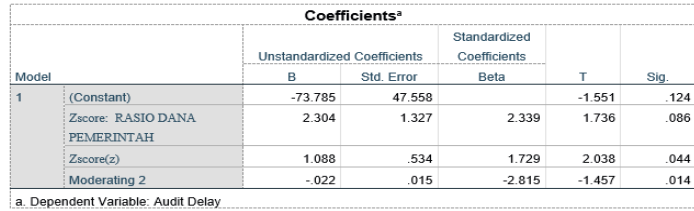

Pada table diatas dapat dilihat bahwa hubungan antara variabel Rasio Dana Pemerintah dengan Ukuran Perguruan Tinggi memiliki koefisien regresi 1,088 dan nilai signifikansi $0,014<0,05$ sehingga hipotesis 4 diterima. Artinya ukuran perguruan memoderasi pengaruh positif rasio dana pemerintah terhadap audit delay. Dilihat bahwa ukuran PTNBH memiliki perngaruh dan memperkuat pengaruh rasio dana pemerintah terhadap audiit delay. Semakin besar ukuran PTNBH akan memiliki total aset yang besar.

\section{Simpulan}

Hasil penelitian ini untuk mengetahui pengaruh reputasi auditor, rasio dana pemerintah terhadap audit delay dengan ukuran perguruan tinggi sebagai variabel moderasi pada Perguruan Tinggi Negeri Badan Hukum tahun 2016 - 2018. Dari hasil pengujian yang dilakukan dalam penelitian ini, peneliti menarik simpulan sebagai berikut:

1. Reputasi Auditor berpengaruh positif terhadap Audit Delay. Karena penggunaan Auditor yang memilki reputasi yang tinggi akan memperpendak audit delay,

2. Rasio Dana Pemerintah berpengaruh positif terhadap Audit Delay. Hal ini menunjukan bahwa semakin tinggi rasio dana pemerintah akan memperpanjang audit delay,

3. Ukuran perguruan tinggi tidak mampu memoderasi pengaruh positif reputasi auditor terhadap audit delay, artinya ukuran PT memperlemah pengaruh reputasi auditor terhadap lamanya audit delay,

4. Ukuran perguruan tinggi mampu memoderasi pengaruh positig dana pemerintah terhadap audit delay, artinya ukuran PT mampu memperkuat pengaruh rasio dana pemerintah terhadap lamanya audit delay. 


\section{Daftar Pustaka}

A. Putra, Andhika Candra dan Wiratmaja, I Dewa Nyoman, 2019, "Pengaruh Profitabilitas Dan Kompleksitas Operasi Pada Audit Delay Dengan Ukuran Perusahaan Sebagai Variabel Moderasi”, E-Jurnal Akuntansi Universitas Udayana

B. Akbar Fabio, 2017, Analisis Pengaruh Ukuran Pemerintah Daerah, Opini Audit dan Leverage terhadap Audit Delay, Jurnal ekonomi bisnis Universitas Lampung

C. Duma Daratika, 2018, Pengaruh Audit Tenure dan Ukuran Perusahaan terhadap Audit Report Lag dengan Reputasi KAP sebagai varibael Moderasi, Jurnal JOM FEB

D. Tullah, Dewi Sarifah, Apriyani, Erma dan Rianti Fitri, 2019, Pengaruh Daerah, Opini Audit, dan Tingkat Ketergantungan keuangan daerah terhadap audit delay, Jurnal ilmiah akuntansi atestasi

E. Dhaifina Risa, 2018, Pengaruh ukuran perusahaan, profitabilitas terhadap audit delay dengan reputasi KAP sebagai variabel moderasi, Universitas Muhammadyah Surakarta

F. Kurnia, Muhtarudin, dan Emylia, 2016, Pengaruh Faktor Keuangan Dan Non Keuangan Terhadap Peringkat Obligasi Pada Perusahaan Non Keuangan Yang Terdaftar Di Bei Periode 20112015

G. Jensen, M., C., dan W. Meckling, 1976. "Theory of the firm: Managerial behavior, agency cost and ownership structure", Journal of Finance Economic 3:305- 360, di-download dari http://www.nhh.no/for/courses/spring/eco420/jens enmeckling-76.pdf.

H. Agoes, Sukrisno. (2014). Auditing Petunjuk Praktis Pemeriksaan Akuntan oleh Akuntan Publik. Edisi ke 4. Buku 1. Jakarta: Salemba Empat

I. Arens, Alvin A., et al. 2011. Auditing dan Jasa Assurance. Jakarta: Erlangga. Alih Bahasa: Herman Wibowo. Editor: Wibi Hardani, dan Suryadi Saat.

J. Undang-Undang Nomor 17 tahun 2003 tentang keuangan negara pasal 30 ayat (1)

K. E. Kieso, Donald, Jerry J, Weygandt and Teery D. Warfield. (2011). Intermediate Accounting, Edisi 12. Jakarta: Erlangga.
L. Fodio, Musa Inuwa, VictorChiedu Oba, Abiodun Bamidele Olukoju and Ahmed Abubakar Zikrullahi. 2015. IFRS Adoption, Firm Traits and Audit Timelines: Evidence from Nigeria. Jurnal Acta Universitatis Danubius.

M. Munsif, V., Raghunandan, K., \& Dasaratha, V. R. 2012. Internal Control Reporting and Audit Report Lags: Further Evidence. Journal Business And Economics Accounting Auditing

N. Ariyani, N. N. T. D., \& Budiartha, I. K. (2014). Pengaruh Profitabilitas, Ukuran Perusahaan, Kompleksitas Operasi Perusahaan Dan Reputasi Kap Terhadap Audit Report Lag Pada Perusahaan Manufaktur. E-Jurnal Akuntansi Universitas Udayana

O. Hardini,Ziza Gita dan Sukirman Sukirman, 2016, Analisis Determinan Audit Delay Pada Pemerintah Kabupaten/Kota Di Indonesia, Jurnal Accounting Analysis Journal

P. Undang-Undang nomor 12 tahun 2012 tentang pendidikan tinggi

Q. Ibrahim, Malik, Alwin , 2016, Pengaruh Profitabilias, Leverage, Reputasi KAP, dan Opini Audit terhadap Audit Delay, Jurnal Ultima Accounting

R. Sari, P. I., dkk. 2014. Pengaruh Ukuran Perusahaan, Solvabilitas, Dan Reputasi KAP Terhadap Audt Delay Pada Perusahaan Property Dan Real Estate di Bursa Efek Indonesia Periode 2009-2012. Jurnal Online Mahasiswa, Fakultas Ekonomi, Universitas Riau.

S. Sugiyono. 2018. Metode Penelitian Kuantitatif. Bandung: Alfabeta 